\title{
The Accuracy of Indonesian Language Rules in Exam Questions Made by Teachers in Junior High School (SMPN) 27 Medan Academic Year 2016-2017 and 2017-2018
}

\author{
Shara Novita ${ }^{1}$, Wisman Hadi ${ }^{2}$, Marice ${ }^{2}$ \\ ${ }^{1}$ Master Student in Indonesia Language, Postgraduate Program, State University of Medan \\ (Unimed), Indonesia \\ ${ }^{2}$ State University of Medan (Unimed), Indonesia \\ sharanovita80@yahoo.co.id
}

\begin{abstract}
Evaluation is the result of the teaching and learning process carried out by teachers and students. Assessment serves to measure students' understanding of the material given by the teacher. Evaluation or procurement activities also play an important role in improving the quality of learning. As for the accuracy of the use of the Indonesian language rules in the class and UAS test exam questions made by Indonesian Language teachers in SMP 27 for the last two years, namely in the total of 195 questions consisting of multiple-choice descriptions, it was found that 86 questions (44\%) were not effective and 99 questions $(51 \%)$ are effective. The most common mistake is the alignment and unity of ideas and economics. The accuracy of the use of the operational word in this study is quite good, because only 5 questions (3\%) are incorrect and 190 other questions (97\%) are stated correctly.
\end{abstract}

Keywords : language rules; examination; learning assessment; technique of writing

\section{Introduction}

Assessment or evaluation is the result of the teaching and learning process carried out by teachers and students. Assessment serves to measure students' understanding of the material given by the teacher. Evaluation or procurement activities also play an important role in improving the quality of learning. The results of the evaluation are the benchmarks of whether the objectives of the learning process have been achieved or not, and can be known which basic competencies, materials or indicators have not been mastered by students. Thus, the test as an evaluation tool must be made correctly.

The statement above reveals that the test prepared must be of good quality because the results of the process are used to improve the quality of education. Therefore, the teacher must be able to arrange the items in order to have a high level of validity, reliability, and have a good difference in power (Sudijono, 2006). To get a quality question, the question maker, especially the teacher, needs to analyze the items that have been made. However, in the SMP Negeri 27 Medan school it was found that the process of making the tested questions had not been carried out maximally. every educational institution is a teacher who plays a role as a writer of questions must refer to the standard of competence and basic competencies that apply in each school. For this reason, it is necessary to make a grid as a reference. This statement is in accordance with Government Regulation Number 23 of 2016 concerning Educational Assessment Standards. One of the government regulations listed is in Article 13 which contains that one of the assessment procedures that must be carried out by educators in the learning process and learning outcomes is to compile a grid of assessments accompanied by an analysis of the quality of the instruments. with the answer key along with information in the form of difficulty level and different power categories. This is in accordance with the question writing guide, specifically the multiple choice form issued by the Ministry of National Education Research and Development Balit Center (2007). 
One of the categories that must be fulfilled in the guideline for writing questions is the category of different power and level of difficulty. This category can only be known if the writer of the question has conducted an analysis of each item he made. For this reason, the writer should examine the problem first in order to find out whether the problem is of high quality or not. However, based on information from one teacher it was known that the questions they made for the exam at the school did not go through a trial process first. This fact contradicts the regulations set by the government regarding the Assessment Standards in 2016 number 23 article 14 which states that the assessment instruments used by educational units in the form of final assessments or school examinations must meet the requirements of substance, construction and language, and have evidence of empirical validity. This regulation clearly shows that in the process the question must be able to represent the competencies assessed, the arrangement of the questions must be in accordance with the form of instrument used, the language used in the question must be communicative in accordance with the applicable rules and the level of student development, and the testing process to obtain the instrument valid. If the problem is not analyzed first, it is certainly difficult to determine whether the instrument is valid or not. Then, a statement emerged that they did not understand how the process of analyzing the quality of questions quantitatively in terms of validity, reliability, power difference, and level of difficulty. As a result, there is no revision (improvement) of the questions that have been made and still tested without knowing the quality.

Another problem found was that the value of student learning outcomes tended not to be in line with expectations even though the description of the questions had been given. Therefore, the assumptions about doubts about the quality of the questions tested were getting stronger after getting information from Indonesian teachers in class IX, Ms. Susilawati Salabi , S.Pd. which states that there are $40 \%$ of students whose test results do not reach the minimum completeness criteria (KKM) of 85.

\subsection{Learning Assessment}

\section{Review of Literature}

Assessing the achievement of student learning outcomes is the main task of a teacher in the learning activities that have been carried out. In essence the assessment activities carried out are not only to assess the learning outcomes of students, but also for various factors, for example to assess the quality of the learning done. Efforts to improve the quality of learning can be pursued through improving the quality of the assessment system.

There are three terms that are often used in the world of education related to assessment, namely assessment, measurement, and testing. According to Nurgiyantoro (2013: 7), assessment is a systematic process in gathering, analyzing, and interpreting information to determine how far a student can achieve educational goals. Measurement is a process to obtain a description of the number (score) that shows the level of achievement of a person in a particular field, for example the answer to the question "how much". A test is a systematic instrument or procedure for measuring a sample of behavior, for example, to answer the question "how good (high) is the performance of someone" whose answer is a number.

According to Widoyoko (2014: 2-4), assessment or assessment can be interpreted as an activity of interpreting or interpreting the results of a measurement data based on criteria or standards or certain rules. Measurement is quantification or determination of numbers about the characteristics or circumstances of individuals according to certain rules. Measurements have a broader concept than tests. Test is a measuring instrument to obtain information on 
student learning outcomes that require answers or responses to right or wrong. The test is the narrowest part of the evaluation.

\subsection{Technique of Writing Description Questions}

The description test in the evaluation process is often used because it can explore students' understanding of the material that has been given. This is reinforced by Sudjana (2016: 35) which states that the description test is a question that requires students to answer it in the form of deciphering, explaining, discussing, comparing, giving reasons, and other similar forms in accordance with the demands of questions using words and language own. Then Widoyoko (2014: 115) explains that the description form test is a question item that contains questions or assignments that answer or work on the question must be done by expressing the thoughts of the test participant. Furthermore, Arikunto (2011: 162) states that essay form tests (descriptions) are a kind of learning progress test that requires answers that are discussion or description of words. The characteristics of the question are preceded by the words described, explain, why, how, compare, conclude, and so on.

Djiwandono (2008: 57) conveyes more specifically the description test referring to the test in which the answer was in the form of a description in various writing styles, such as descriptive and argumentative, according to the problems that were the subject matter. Furthermore, Purwanto (2017: 70-71) explains that the description test is a form of test consisting of questions or instructions that require answers in the form of relatively long descriptions. Forms of questions or instructions ask students to explain, compare, interpret, and look for differences.

All forms of these questions hope that students show their understanding of the material being studied. Descriptive tests are used to overcome weaknesses in measuring objective questions that are limited to low learning outcomes. Furthermore, Siburian (2015: 115) argues that answer unraveling tests are a test arranged with relatively short questions and answers requested from students in free descriptions

\subsection{Characteristics of a Good Test}

A good test tool is a test whose measurement results can provide a real picture of the ability of the test participant in a particular field to be the target of measurement. Brown (2014) in the LLT Journal entitled Content Validity and Authenticity of the 2012 English Test in the Senior High School National Examination stated that "The test should meet a good test's criteria, for instances: reliability, validity, practicality, and authenticity" which means that a test must meet good test criteria, namely reliability, validity, practicality, and authenticity.

A similar opinion was also stated by Arikunto (2011: 57: 58) that the test as a measuring device must meet the test requirements, which have validity, reliability, objectivity, practice, and economics. The same thing was also conveyed by Sudijono (2011: 93) that at least there are four characteristics or characteristics that must be possessed by the learning outcome test, so that the test can be stated as a good test, which is valid, reliable, objective, and practical. Widoyoko (2014: 139-142) has a similar opinion that the characteristics of a good test are tests that have validity, reliability, objectivity, practice, and economics. Widoyoko (2014: 131) adds that for the test of learning outcomes it is generally considered three characteristics of the items, namely difficulty index, discriminating power, and distractor effectiveness.

Slightly different from the two opinions above, Sudjana (2016: 12) states that an assessment tool is said to have good quality if the tool has or fulfills two things, namely its accuracy (validity) and determination / reliability (reliability). This opinion is in line with 
Djowandono (2008: 163) that evaluation is expected to be able to provide feedback for the implementation of overall learning. Therefore, it needs to be done well and by using the test as a quality and accountable tool and has the required characteristics, especially validity, reliability, in addition to other characteristics.

\subsection{Analysis of Learning Outcomes Tests}

Test analysis is the identification of correct answers and wrong questions for each student tested. Through the analysis work, which items will be known which are answered correctly by the test participants and vice versa, which items are also answered incorrectly. Based on the number of correct and wrong answers by the students, then the difficulty level index can be calculated for each item and other things needed. Oller (1979: 245) states "Item analysis is an important preparation for good multiple choice tests." Which means that it is important to analyze items to prepare several good choice tests.

In addition, Nurgiyantoro (2013: 190) states that the analysis of the items is an assessment of the quality of the items in a test to test the effectiveness of the items. Test kits that are well supported by items that are good, effective, can be accounted for. Question analysis is an analysis of the relationship between item scores and the overall score, comparing students' answers to a question item with answers to the overall test.

Here are some reasons why item analysis is needed according to Widoyoko (2014: 130-131).

a. To be able to know the strengths and weaknesses of the test items, so that good or bad items can be determined.

b. To provide information about the specifications of the item in full, so that it will make it easier for the teacher in preparing a set of questions that will meet the needs of the test in certain fields and levels.

c. To be able to find out the problems contained in the items such as errors put the answer key, the questions that are too difficult or too easy, or questions that can not distinguish students who prepare well or not in the face of the exam. This problem, if it can be known immediately, will allow the teacher to make a decision whether the items in question will be aborted or not in determining the value of students.

d. To be used as a tool to assess the items to be stored in the question bank. If a teacher already has a number of items (bank questions) that are good, then he will easily be able to arrange a set of questions that are good to use in accordance with the objectives. To obtain information about items so that it is possible to compile a number of parallel questions. The preparation of devices like this is very useful if you will do a repeat test or measure the learning outcomes of several groups of students at different times.

\subsection{Indonesian Language Rules in Writing Questions}

The proper use of the rules of the Indonesian language in the process of writing questions is one of the determinants of the success of students in answering questions. This is supported by Oler (1979: 13) who states "Because the evaluation of the questions prepared by teachers can measure success in learning, then the test questions should be prepared by considering the rules of language use" which means that the evaluation questions prepared by the teacher can serves as a measure of the success of learning, the test questions must be compiled by taking into account the rules of the language they use. Therefore, for the makers of this understanding of the rules of Indonesian language, it is very important. This is in line with Safari's opinion (1995: 3) stating that teachers must pay attention to the use of language in the problem writing 
process. He also added that it was unfortunate because in reality the teacher often ignored it so that there were some mistakes. The following are common mistakes.
a. the composition of the question statement is convoluted or long-winded.
b. the words in the question statement are unclear.
c. use incorrect punctuation.
d. incorrect use of capital letters and incorrect writing of prepositions.

\section{Research Method}

This research is a type of descriptive research case study with a quantitative-qualitative approach. The quantitative approach used in this study is to calculate the results of the analysis of the quality of the items that are systematically, planned, and clearly structured and in this study obtained in the form of numbers generated from statistical calculations (Sudijono, 2010). The quality of the question is examined quantitatively, namely by analyzing the test results of the test questions that are reviewed in terms of validity, reliability, level of difficulty, power difference, and the effectiveness of deception. Furthermore, a qualitative approach will be used to accompany and complete the picture obtained from quantitative data and to analyze the accuracy of the use of Indonesian in the problem.

According to Arikunto (2013: 3) the term "descriptive" comes from the English term to describe which means describing or describing things, such as circumstances, conditions, situations, events, activities, and others. Thus, what is meant by descriptive research is research intended to investigate the circumstances, conditions, or other things that have been mentioned, the results of which are presented in the form of research reports.

This research was conducted at SMPN 27 Medan, having its address at Jalan Pancing, Pasar IV No. 2, 20223, Besar, Medan Tembung, New Memories, Percut Sei Tuan. Based on the considerations and preliminary observations that have been made, the study that will be examined is the quality of the questions made by Indonesian teachers in this school. The most basic reason is because of the problems found for research originating from the school. In addition, no similar research has been conducted. Then, when the research is conducted from July to November 2018.

The subjects in this study were exam questions made by Indonesian language teachers at SMPN 27 Medan, namely the increase in class exam questions in even semester VII and VIII in 2016-2017 in the form of 30 essay questions and 5 essay / strata questions. then the UAS class IX questions as many as 40 multiple choice questions and 5 essay questions, then the exam questions class VII and VIII in 2017-2018 in the form of essays of 35 multiple choice questions and 5 essay / strata questions, with the total number in the last two years as many 195 questions. The questions studied were exam questions tested in the 2016-2017 school year and 2017-2018. The object in this study is the quality of the exam questions that are reviewed in terms of validity, reliability, level of difficulty, difference in power, and effectiveness of deception. In addition, the accuracy of the use of Indonesian language rules in the exam question text was also the object of this study.

\section{Discussion}


The following is an explanation of the results of the analysis of the accuracy of the Indonesian language rules in the SMPN 27 Medan exam question text based on effective sentence fields, the use of operational words, the accuracy of capital letters and punctuation.

The accuracy of effective use of sentences in writing questions aims to make the intentions conveyed in the problem clear. The sentence used in the problem can determine the success of students answering the question (Safari, 1995: 3).

\subsection{The accuracy of effective sentences in the eleventh grade exam text for the 2016-2017}

It shows that as many as $26(74 \%)$ questions from 35 questions have ineffective sentences. The area of error that is often found is in the unity of alignment of forms and economies. Following is the explanation table.

Table 1. Results of the Accuracy Analysis of Effective Sentence of Exam Questions Class VII Academic Year 2016-2017

\begin{tabular}{|c|c|c|c|c|c|}
\hline Class & $\begin{array}{l}\text { Types of } \\
\text { Question }\end{array}$ & $\begin{array}{l}\text { Number of } \\
\text { Questions }\end{array}$ & $\begin{array}{c}\text { Total } \\
\%\end{array}$ & $\begin{array}{l}\text { Ineffective } \\
\text { Questions }\end{array}$ & Error Field \\
\hline \multirow[t]{26}{*}{ VII } & \multirow{22}{*}{$\begin{array}{l}\text { Multiple } \\
\text { choice }\end{array}$} & \multirow{22}{*}{$\begin{array}{l}22 \\
\text { questions }\end{array}$} & \multirow[t]{26}{*}{$74 \%$} & 1 & Unity and form misalignment \\
\hline & & & & 3 & Unity and misalignment of form \\
\hline & & & & 4 & Misalignment of form \\
\hline & & & & 6 & Emphasis \\
\hline & & & & 8 & $\begin{array}{l}\text { Unity and alignment of forms, } \\
\text { reduction }\end{array}$ \\
\hline & & & & 9 & Unity \\
\hline & & & & 11 & Unity and alignment of form \\
\hline & & & & 13 & Unity and misalignment of form \\
\hline & & & & 14 & Unity of ideas \\
\hline & & & & 15 & Unity \\
\hline & & & & 16 & $\begin{array}{l}\text { Unity and alignment of form, } \\
\text { emphasis }\end{array}$ \\
\hline & & & & 18 & Reduction \\
\hline & & & & 19 & Unity \\
\hline & & & & 20 & Unity \\
\hline & & & & 21 & Unity \\
\hline & & & & 22 & Alignment of forms \\
\hline & & & & 23 & Reduction \\
\hline & & & & 25 & Reduction \\
\hline & & & & 26 & Unity of form and emphasis \\
\hline & & & & 27 & Emphasis \\
\hline & & & & 29 & Unity of ideas \\
\hline & & & & 30 & Unity of ideas and emphasis \\
\hline & \multirow[t]{4}{*}{ Essay } & \multirow[t]{4}{*}{4 Questions } & & 2 & Unity of ideas \\
\hline & & & & 3 & Reduction \\
\hline & & & & 4 & Reduction \\
\hline & & & & 5 & Reduction \\
\hline
\end{tabular}




\subsection{The Accuracy of Effective Sentences for Exam Questions in Class VIII for the 2016- 2017 Academic Year.}

Errors in the use of effective sentences in class VIII exam texts show fewer results, namely 13 questions (37\%) of the total questions 35. Errors found in multiple choice questions are mainly in the area of unity and form alignment.

Table 2. Results of the Accuracy Analysis of Effective Sentence of Exam Questions Class VIII Academic Year 2016-2017

\begin{tabular}{|c|c|c|c|c|c|}
\hline Class & $\begin{array}{l}\text { Types of } \\
\text { Ouestion }\end{array}$ & $\begin{array}{l}\text { Number of } \\
\text { Ouestions }\end{array}$ & $\begin{array}{c}\text { Total } \\
\%\end{array}$ & $\begin{array}{l}\text { Ineffective } \\
\text { Ouestions }\end{array}$ & Error Field \\
\hline \multirow[t]{14}{*}{ VIII } & \multirow[t]{13}{*}{$\begin{array}{l}\text { Multiple } \\
\text { choice }\end{array}$} & \multirow[t]{13}{*}{$\begin{array}{l}13 \\
\text { questions }\end{array}$} & \multirow[t]{14}{*}{$37 \%$} & (nom & $\begin{array}{l}\text { Unity and alignment of forms, } \\
\text { reduction }\end{array}$ \\
\hline & & & & 4 & Reduction \\
\hline & & & & 8 & Unity of ideas \\
\hline & & & & 9 & Alignment of forms \\
\hline & & & & 13 & Alignment of forms \\
\hline & & & & 14 & Reduction \\
\hline & & & & 15 & Unity and alignment of forms \\
\hline & & & & 16 & Unity and alignment of forms \\
\hline & & & & 17 & $\begin{array}{l}\text { Kesatuan dan kesejaja Unity and } \\
\text { alignment of forms ran bentuk }\end{array}$ \\
\hline & & & & 23 & Reduction \\
\hline & & & & 24 & Emphasis \\
\hline & & & & 25 & Reduction \\
\hline & & & & 26 & Unity of ideas \\
\hline & Essay & - & & - & - \\
\hline
\end{tabular}

4.3 Accuracy of Effective Sentences for Exam Questions in Class IX of the 2016-2017 Academic Year.

The most prominent mistake in the accuracy of the use of effective sentences in class IX is form alignment. The number of inaccuracies found is as much as $17 \%$ with the number 8 questions in the multiple choice questions of the total questions 3 . To be clearer, it can be seen in the following table.

Table 3. Results of the Accuracy Analysis of Effective Sentence of Exam Questions Class IX Academic Year 2016-2017

\begin{tabular}{|l|l|c|c|c|c|}
\hline Class & $\begin{array}{c}\text { Types of } \\
\text { Question }\end{array}$ & $\begin{array}{c}\text { Number of } \\
\text { Questions }\end{array}$ & $\begin{array}{c}\text { Total } \\
\%\end{array}$ & $\begin{array}{c}\text { Ineffective } \\
\text { Questions }\end{array}$ & Error Field \\
\hline IX & $\begin{array}{l}\text { Multiple } \\
\text { choice }\end{array}$ & 8 & $17 \%$ & 3 & Alignment of forms \\
\cline { 4 - 6 } & & & 8 & Alignment of forms \\
\hline
\end{tabular}




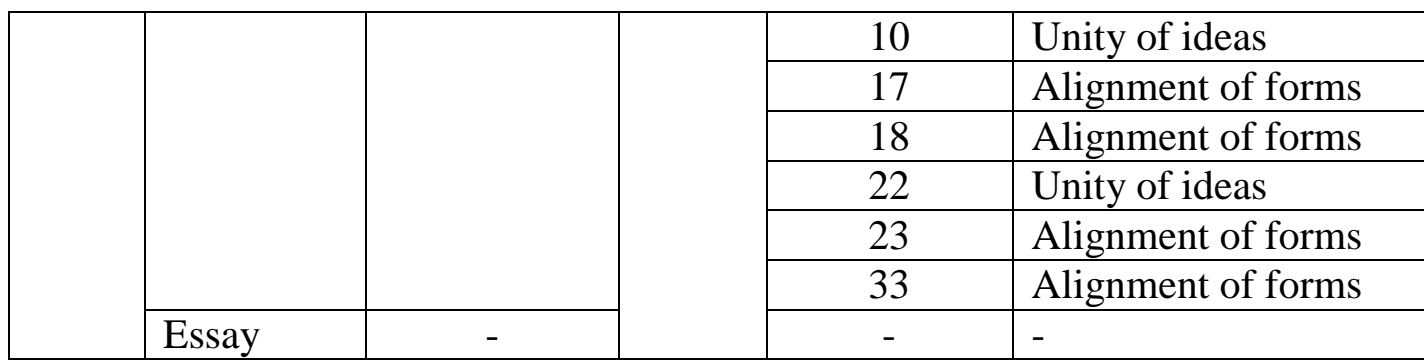

\subsection{Accuracy of Effective Sentences of Exam Questions in Class VII of Academic Year 2017-2018.}

Inaccurate use of effective sentences in class VII exam texts for the 2017-2018 school year as many as $65 \%$ with 26 questions out of a total of 40 questions consisting of 35 multiple choices and 5 descriptions. The amount of $65 \%$ indicates that more than half of the questions are made without regard to the sentence in the question. Here are the details.

Table 4. Results of the Accuracy Analysis of Effective Sentence of Exam Questions Class VII Academic Year 2017-2018

\begin{tabular}{|c|c|c|c|c|c|}
\hline Class & $\begin{array}{l}\text { Types of } \\
\text { Question }\end{array}$ & $\begin{array}{l}\text { Number of } \\
\text { Questions }\end{array}$ & $\begin{array}{c}\text { Total } \\
\%\end{array}$ & $\begin{array}{l}\text { Ineffective } \\
\text { Questions }\end{array}$ & Error Field \\
\hline \multirow[t]{18}{*}{ VII } & \multirow{18}{*}{$\begin{array}{l}\text { Multiple } \\
\text { choice }\end{array}$} & \multirow[t]{18}{*}{22 question } & \multirow[t]{18}{*}{$65 \%$} & 1 & Unity of ideas and form alignment \\
\hline & & & & 3 & $\begin{array}{l}\text { Unity of ideas and alignment of } \\
\text { forms, emphasis, variance }\end{array}$ \\
\hline & & & & 4 & form alignment \\
\hline & & & & 6 & Emphasis \\
\hline & & & & 8 & $\begin{array}{l}\text { Unity of ideas and alignment of } \\
\text { forms, emphasis, variance }\end{array}$ \\
\hline & & & & 9 & $\begin{array}{l}\text { Unity of ideas, economics, } \\
\text { emphasis }\end{array}$ \\
\hline & & & & 11 & Unity of ideas \\
\hline & & & & 13 & $\begin{array}{l}\text { Unity and alignment of forms, } \\
\text { economics }\end{array}$ \\
\hline & & & & 14 & $\begin{array}{l}\text { Unity and alignment of forms, } \\
\text { reduction }\end{array}$ \\
\hline & & & & 15 & $\begin{array}{l}\text { Unity of ideas and form alignment, } \\
\text { emphasis }\end{array}$ \\
\hline & & & & 16 & $\begin{array}{l}\text { Unity and form alignment, } \\
\text { emphasis }\end{array}$ \\
\hline & & & & 18 & Reduction \\
\hline & & & & 19 & Unity of ideas \\
\hline & & & & 20 & $\begin{array}{l}\text { Unity of ideas and unity of form, } \\
\text { emphasis }\end{array}$ \\
\hline & & & & 21 & Unity of ideas \\
\hline & & & & 22 & Alignment of forms \\
\hline & & & & 23 & Reduction \\
\hline & & & & 25 & Reduction \\
\hline
\end{tabular}




\begin{tabular}{|c|c|c|c|}
\hline & & 26 & $\begin{array}{l}\text { Unity of ideas and form alignment, } \\
\text { emphasis }\end{array}$ \\
\hline & & 27 & Emphasis \\
\hline & & 29 & Unity of ideas \\
\hline & & 30 & $\begin{array}{l}\text { Unity of ideas and form alignment, } \\
\text { emphasis, reduction }\end{array}$ \\
\hline Essay & 4 questions & 2 & Unity of ideas, emphasis \\
\hline & & 3 & Reduction \\
\hline & & 4 & Reduction \\
\hline & & 5 & Reduction \\
\hline
\end{tabular}

\subsection{Accuracy in the Use of Capital Letters and Punctuation in Class VIII Exam Questions for the 2016-2017 Academic Year}

The results of the analysis of the increase in class VIII exam text for the 2016-2017 school year showed that there were 18 inaccuracies in the use of capital letters and punctuation marks (51.4\%), the most common error being the use of capital letters. The following table details.

Table 5. Results of the Accuracy Analysis of the Use of Capital Letters and Punctuation Class VIII Academic Year 2016-2017

\begin{tabular}{|c|c|c|c|c|c|}
\hline Class & $\begin{array}{l}\text { Types of } \\
\text { Question }\end{array}$ & $\begin{array}{l}\text { Number of } \\
\text { Questions }\end{array}$ & $\begin{array}{c}\text { Total } \\
\%\end{array}$ & $\begin{array}{l}\text { Ineffective } \\
\text { Questions }\end{array}$ & Error Field \\
\hline \multirow[t]{13}{*}{ VIII } & \multirow{12}{*}{$\begin{array}{l}\text { Multiple } \\
\text { choice }\end{array}$} & \multirow[t]{12}{*}{12 questions } & \multirow[t]{13}{*}{$32,5 \%$} & 6 & Alignment of forms \\
\hline & & & & 7 & $\begin{array}{l}\text { Unity of ideas and form } \\
\text { alignment, emphasis }\end{array}$ \\
\hline & & & & 14 & Unity of ideas \\
\hline & & & & 15 & Alignment of forms \\
\hline & & & & 19 & Alignment of forms \\
\hline & & & & 20 & Reduction \\
\hline & & & & 21 & Unity of ideas \\
\hline & & & & 22 & Alignment of forms \\
\hline & & & & 25 & Reduction \\
\hline & & & & 27 & Reduction \\
\hline & & & & 28 & Reduction \\
\hline & & & & 34 & Reduction \\
\hline & Essay & 1 question & & 3 & Kesatuan gagasan, kehematan \\
\hline
\end{tabular}

4.6 Use of Operational Words in Questions Made by Indonesian Language Teachers in SMPN 27 Medan Academic Year 2016-2017 and 2017-2018

The accuracy of the use of the operational word tested in SMPN 27 Medan can be said to be almost right in general because of the 195 questions there are only 5 questions $(2.6 \%)$ which use the operational word is not appropriate, ie 4 questions are in the form of class VII and 1 multiple choice the question in the form of description class VIII. The following table details.

Table 6. Results of the Accuracy Analysis of the Use of Operational Words 


\begin{tabular}{|l|l|l|l|}
\hline $\begin{array}{l}\text { School } \\
\text { year }\end{array}$ & \multirow{2}{*}{ Class } & Types of Question & Improper Question \\
\hline \multirow{2}{*}{$\begin{array}{l}2017 / 201 \\
8\end{array}$} & \multirow{2}{*}{ VII } & Multiple choice & $6,13,16$, dan 26 \\
\cline { 2 - 4 } & \multirow{2}{*}{ VIII } & Essay & - \\
\hline \multicolumn{2}{|c|}{ Total } & Multiple choice & - \\
\cline { 3 - 4 } & Essay & 4 \\
\hline \multicolumn{2}{|l}{} & $\mathbf{4}$ questions \\
\hline
\end{tabular}

\subsection{Use of Capital Letters and Punctuation in Exam Questions Made by Teachers in SMPN 27 Medan Academic Year 2016-2017 and 2017-2018}

The use of capital letters and punctuation in the Indonesian language exam text in class VII 2016-2017 was stated to be almost not entirely correct, because of the high number of errors found which reached $97 \%$ (34 incorrect questions from a total of 40 questions). The most prominent error found is improper punctuation. To be clearer, it can be noted in the following table.

Table 7. Results of the Accuracy Analysis of the Use of Capital Letters and Punctuation Class VII Academic Year 2016-2017

\begin{tabular}{|c|c|c|c|c|c|}
\hline Class & $\begin{array}{l}\text { Types of } \\
\text { Question }\end{array}$ & $\begin{array}{l}\text { Total of } \\
\text { Questions }\end{array}$ & $\begin{array}{l}\text { Total } \\
\%\end{array}$ & $\begin{array}{l}\text { Incorrect } \\
\text { Question } \\
\text { Number }\end{array}$ & Error Field \\
\hline \multirow[t]{13}{*}{ VII } & \multirow[t]{13}{*}{$\begin{array}{l}\text { Multiple } \\
\text { choice }\end{array}$} & \multirow[t]{13}{*}{$\begin{array}{l}30 \\
\text { questions }\end{array}$} & \multirow[t]{13}{*}{$97 \%$} & 1 & $\begin{array}{l}\text { Capital letters and } \\
\text { punctuation }\end{array}$ \\
\hline & & & & 2 & Punctuation \\
\hline & & & & 3 & $\begin{array}{l}\text { Capital letters and } \\
\text { punctuation }\end{array}$ \\
\hline & & & & 4 & Punctuation \\
\hline & & & & 5 & $\begin{array}{l}\text { Capital letters and } \\
\text { punctuation }\end{array}$ \\
\hline & & & & 6 & $\begin{array}{l}\text { Capital letters and } \\
\text { punctuation }\end{array}$ \\
\hline & & & & 7 & $\begin{array}{l}\text { Capital letters and } \\
\text { punctuation }\end{array}$ \\
\hline & & & & 8 & Punctuation \\
\hline & & & & 9 & $\begin{array}{l}\text { Capital letters and } \\
\text { punctuation }\end{array}$ \\
\hline & & & & 10 & $\begin{array}{l}\text { Capital letters and } \\
\text { punctuation }\end{array}$ \\
\hline & & & & 11 & Punctuation \\
\hline & & & & 12 & Punctuation \\
\hline & & & & 13 & $\begin{array}{l}\text { Capital letters and } \\
\text { punctuation }\end{array}$ \\
\hline
\end{tabular}




\begin{tabular}{|c|c|c|c|}
\hline & & 14 & $\begin{array}{l}\text { Capital letters and } \\
\text { punctuation }\end{array}$ \\
\hline & & 15 & Punctuation \\
\hline & & 16 & $\begin{array}{l}\text { Capital letters and } \\
\text { punctuation }\end{array}$ \\
\hline & & 17 & $\begin{array}{l}\text { Capital letters and } \\
\text { punctuation }\end{array}$ \\
\hline & & 18 & Punctuation \\
\hline & & 19 & $\begin{array}{l}\text { Capital letters and } \\
\text { punctuation }\end{array}$ \\
\hline & & 20 & Punctuation \\
\hline & & 21 & Punctuation \\
\hline & & 22 & Punctuation \\
\hline & & 23 & $\begin{array}{l}\text { Capital letters and } \\
\text { punctuation }\end{array}$ \\
\hline & & 24 & Punctuation \\
\hline & & 25 & Punctuation \\
\hline & & 26 & Punctuation \\
\hline & & 27 & Punctuation \\
\hline & & 28 & Punctuation \\
\hline & & 29 & Punctuation \\
\hline & & 30 & Punctuation \\
\hline Essay & 4 questions & 2 & Punctuation \\
\hline & & 3 & Punctuation \\
\hline & & 4 & Punctuation \\
\hline & & 5 & Punctuation \\
\hline
\end{tabular}

\subsection{The Accuracy of the Use of Capital Letters and Punctuation in the Class VIII Exam Questions for the 2016-2017 Academic Year}

The results of the analysis of the increase in class VIII exam text for the 2016-2017 school year showed that there were 18 inaccuracies in the use of capital letters and punctuation marks (51.4\%), the most common error being the use of capital letters. The following table details.

Table 8. Results of the Accuracy Analysis of the Use of Capital Letters and Punctuation Class VIII Academic Year 2016-2017

\begin{tabular}{|c|c|c|c|c|c|}
\hline Class & $\begin{array}{l}\text { Types of } \\
\text { Question }\end{array}$ & $\begin{array}{l}\text { Total of } \\
\text { Questions }\end{array}$ & $\begin{array}{l}\text { Total } \\
\%\end{array}$ & $\begin{array}{l}\text { Incorrect } \\
\text { Question } \\
\text { Number }\end{array}$ & Error Field \\
\hline \multirow[t]{7}{*}{ VIII } & \multirow{7}{*}{$\begin{array}{l}\text { Multiple } \\
\text { choice }\end{array}$} & \multirow{7}{*}{$\begin{array}{l}18 \\
\text { questions }\end{array}$} & \multirow[t]{7}{*}{$51,4 \%$} & 2 & Capital letters \\
\hline & & & & 3 & Capital letters \\
\hline & & & & 4 & Capital letters \\
\hline & & & & 8 & Capital letters \\
\hline & & & & 9 & Capital letters \\
\hline & & & & 10 & Capital letters \\
\hline & & & & 11 & Capital letters \\
\hline
\end{tabular}




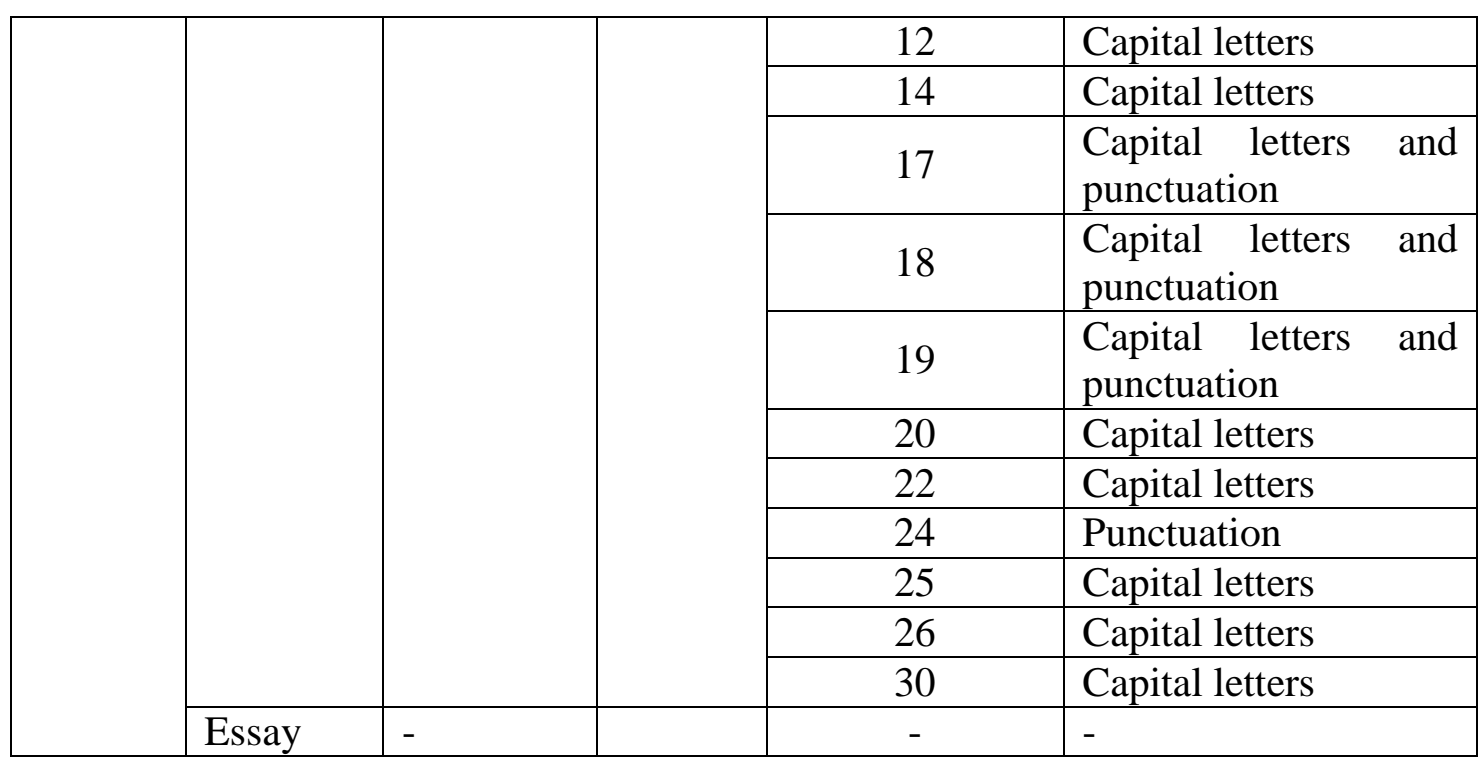

\subsection{Accuracy in the Use of Capital Letters and Punctuation in Class IX Exam Questions} for the 2016-2017 Academic Year

The use of capital letters and punctuation in the text class IX Final Examination questions (UAS) shows that as many as $82 \%$ (37 multiple choice questions and 1 description) of all 45 questions were stated to be incorrect. The most common area of error is the use of punctuation errors, so that more clearly can be seen in the table below.

Table 9. Results of the Accuracy Analysis of the Use of Capital Letters and Punctuation Class IX Academic Year 2016-2017

\begin{tabular}{|c|c|c|c|c|c|}
\hline Class & $\begin{array}{l}\text { Types of } \\
\text { Question }\end{array}$ & $\begin{array}{l}\text { Total of } \\
\text { Questions }\end{array}$ & $\begin{array}{l}\text { Total } \\
\%\end{array}$ & $\begin{array}{l}\text { Incorrect } \\
\text { Question } \\
\text { Number }\end{array}$ & Error Field \\
\hline \multirow[t]{17}{*}{ IX } & \multirow{17}{*}{$\begin{array}{l}\text { Multiple } \\
\text { choice }\end{array}$} & \multirow[t]{17}{*}{37} & \multirow[t]{17}{*}{$82 \%$} & 1 & Punctuation \\
\hline & & & & 2 & Punctuation \\
\hline & & & & 3 & Punctuation \\
\hline & & & & 4 & Punctuation \\
\hline & & & & 5 & Punctuation \\
\hline & & & & 6 & Punctuation \\
\hline & & & & 7 & Punctuation \\
\hline & & & & 8 & Punctuation \\
\hline & & & & 9 & Punctuation \\
\hline & & & & 10 & Punctuation \\
\hline & & & & 11 & Punctuation \\
\hline & & & & 12 & Punctuation \\
\hline & & & & 13 & Punctuation \\
\hline & & & & 14 & Punctuation \\
\hline & & & & 15 & Capital letters \\
\hline & & & & 16 & Punctuation \\
\hline & & & & 17 & Punctuation \\
\hline
\end{tabular}




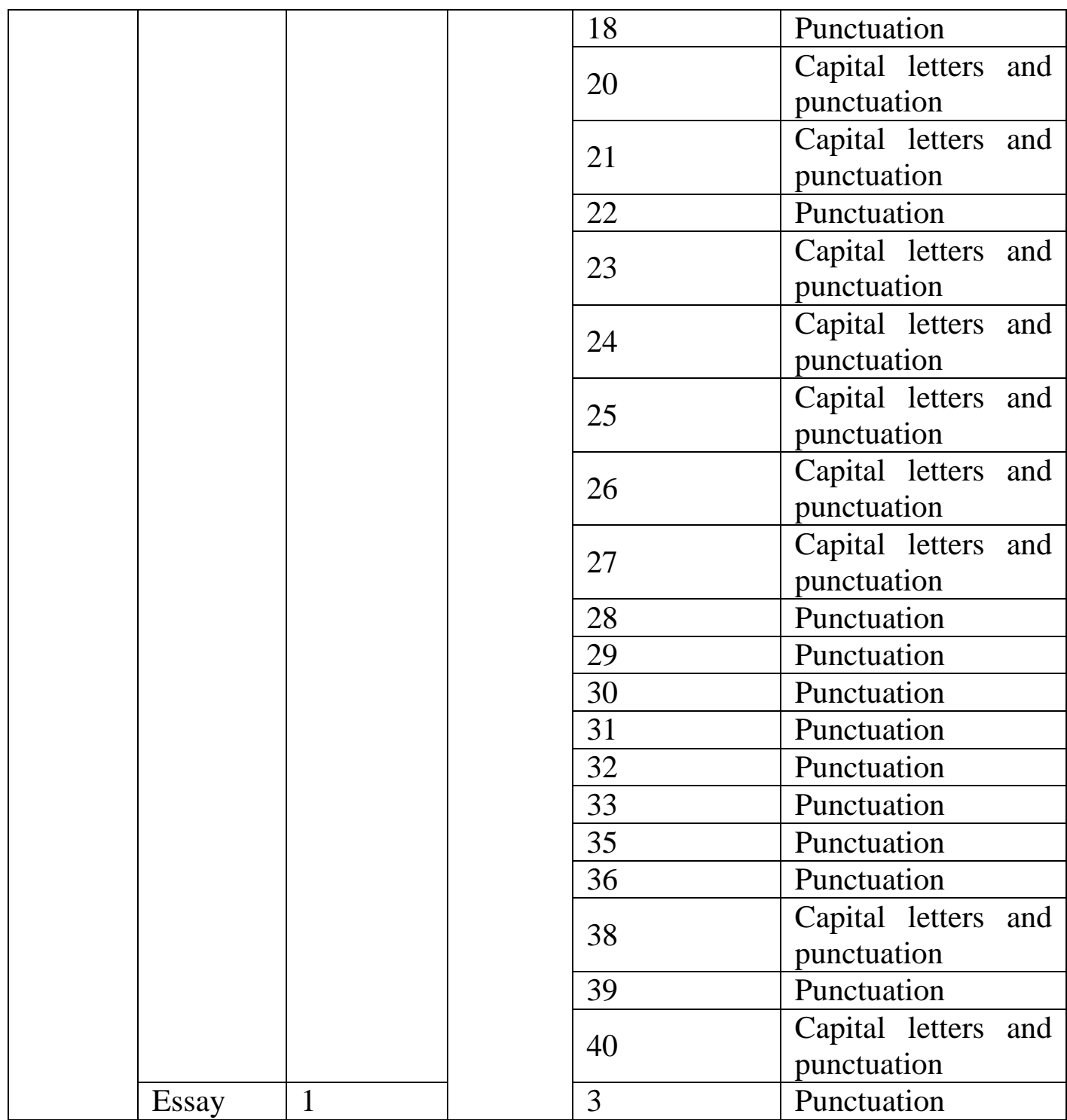

\subsection{Accuracy in the Use of Capital Letters and Punctuation in Class VII Exam Questions for the Academic Year 2017-2018}

The highest number in the field of inaccuracies in capital letters and punctuation is found in the text of the class VII exam in 2017-2018, namely as many as $97.5 \%$ or 39 questions out of a total of 45 questions tested with details of 35 multiple choice questions and 4 description forms. The following table details.

Table 10. Results of the Accuracy Analysis of the Use of Capital Letters and Punctuation Class VII Academic Year 2017-2018

\begin{tabular}{|l|l|l|l|l|ll|}
\hline Class & $\begin{array}{l}\text { Types of } \\
\text { Question }\end{array}$ & $\begin{array}{l}\text { Total of } \\
\text { Questions }\end{array}$ & $\begin{array}{l}\text { Total } \\
\%\end{array}$ & $\begin{array}{l}\text { Incorrect } \\
\text { Question } \\
\text { Number }\end{array}$ & Error Field & \\
\hline VII & $\begin{array}{l}\text { Multiple } \\
\text { choice }\end{array}$ & $\begin{array}{l}35 \\
\text { questions }\end{array}$ & $97,5 \%$ & 1 & $\begin{array}{l}\text { Capital letters and } \\
\text { punctuation }\end{array}$ \\
\cline { 4 - 6 }
\end{tabular}




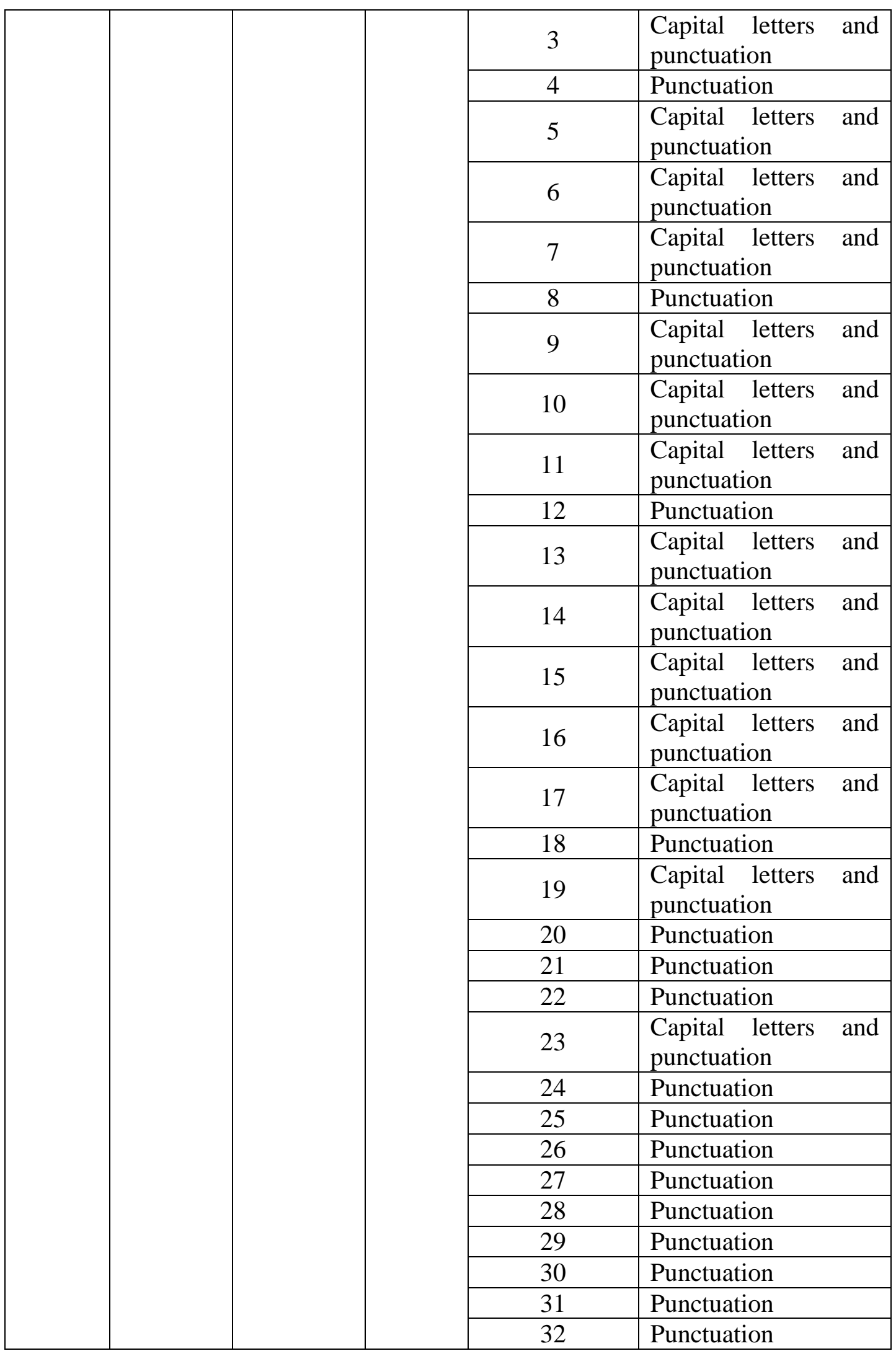




\begin{tabular}{|c|c|c|c|}
\hline & & 33 & $\begin{array}{l}\text { Capital letters and } \\
\text { punctuation }\end{array}$ \\
\hline & & 34 & Punctuation \\
\hline & & 35 & Punctuation \\
\hline \multirow[t]{4}{*}{ Essay } & \multirow[t]{4}{*}{$\begin{array}{l}4 \\
\text { Questions }\end{array}$} & 2 & $\begin{array}{l}\text { Capital letters and } \\
\text { punctuation }\end{array}$ \\
\hline & & 3 & $\begin{array}{l}\text { Capital letters and } \\
\text { punctuation }\end{array}$ \\
\hline & & 4 & Punctuation \\
\hline & & 5 & Punctuation \\
\hline
\end{tabular}

\subsection{The Accuracy of the Use of Capital Letters and Punctuation in Class VIII Exam} Questions for the Academic Year 2017-2018

The inaccuracy of the use of capital letters and punctuation found in the class VIII questions reached $67.5 \%$ (27 multiple choice questions from the total problem 40) with the most common error fields being the use of capital letters. More detailed information will be presented in the following table.

Table 11. Results of the Accuracy Analysis of the Use of Capital Letters and Punctuation Class VIII Academic Year 2017-2018

\begin{tabular}{|c|c|c|c|c|c|}
\hline Class & $\begin{array}{l}\text { Types of } \\
\text { Question }\end{array}$ & $\begin{array}{l}\text { Total of } \\
\text { Questions }\end{array}$ & $\begin{array}{l}\text { Total } \\
\%\end{array}$ & $\begin{array}{l}\text { Incorrect } \\
\text { Question } \\
\text { Number }\end{array}$ & Error Field \\
\hline \multirow[t]{20}{*}{ VIII } & \multirow{20}{*}{$\begin{array}{l}\text { Multiple } \\
\text { choice }\end{array}$} & \multirow{20}{*}{$\begin{array}{l}27 \\
\text { Questions }\end{array}$} & \multirow[t]{20}{*}{$67,5 \%$} & 1 & Capital letters \\
\hline & & & & 5 & Capital letters \\
\hline & & & & 6 & Capital letters \\
\hline & & & & 7 & Capital letters \\
\hline & & & & 8 & Capital letters \\
\hline & & & & 9 & Capital letters \\
\hline & & & & 13 & Capital letters \\
\hline & & & & 14 & Capital letters \\
\hline & & & & 16 & Capital letters \\
\hline & & & & 17 & Punctuation \\
\hline & & & & 18 & Capital letters \\
\hline & & & & 19 & $\begin{array}{l}\text { Capital letters and } \\
\text { punctuation }\end{array}$ \\
\hline & & & & 20 & Capital letters \\
\hline & & & & 21 & Capital letters \\
\hline & & & & 22 & Capital letters \\
\hline & & & & 23 & Capital letters \\
\hline & & & & 24 & Capital letters \\
\hline & & & & 25 & Capital letters \\
\hline & & & & 26 & Capital letters \\
\hline & & & & 27 & Capital letters \\
\hline
\end{tabular}




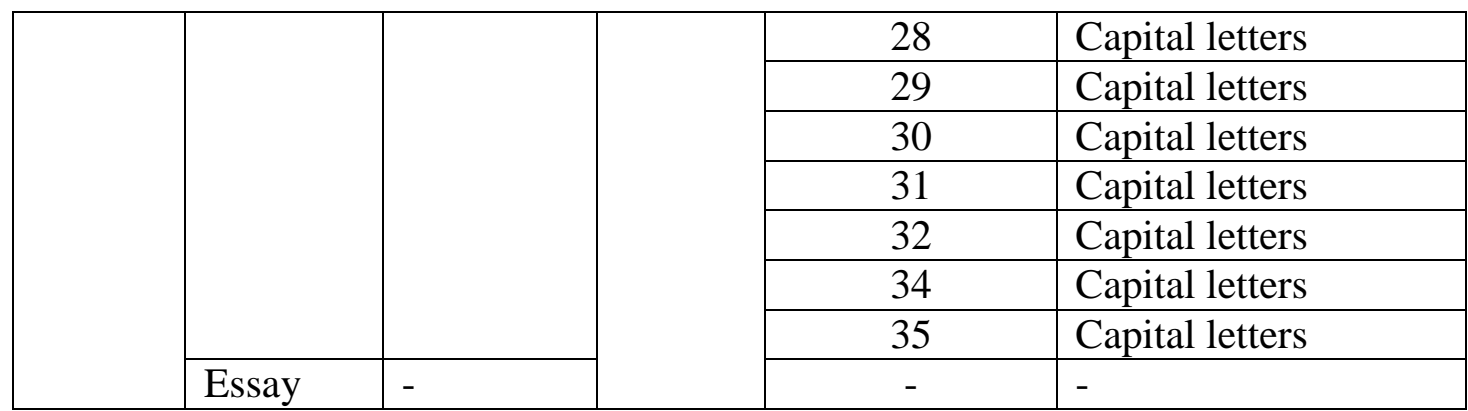

\section{Conclusion}

As for the accuracy of the use of the Indonesian language rules in the class and UAS test exam questions made by Indonesian Language teachers in SMP 27 for the last two years, namely in the total of 195 questions consisting of multiple-choice descriptions, it was found that 86 questions (44\%) were not effective and 99 questions (51\%) are effective. The most common mistake is the alignment and unity of ideas and economics. The accuracy of the use of the operational word in this study is quite good, because only 5 questions (3\%) are incorrect and 190 other questions (97\%) are stated correctly. Judging from the aspect of the accuracy of the use of punctuation and capital letters, it turns out that the number of errors reached a fairly high number of 156 questions (80\%) were incorrect and only 39 questions (20\%) were correct.

\section{References}

Alias. 2015. Kualitas Soal Matematika Ujian Akhir Semester di SDN Se-Wilayah III Kecamatan Donri Donri. Jurnal Konferensi Ilmiah Tahunan Himpunan Evaluasi Pendidikan Indonesia (HEPI).

Amalia, Ata Nayla dan Ani Widayati. 2012. Analisis Butir Soal Tes Kendali Mutu Kelas XII SMA Mata Pelajaran Ekonomi Akuntansi di Kota Yogyakarta Tahun 2012. Jurnal Pendidikan Akuntansi Indonesia. Universitas Negeri Yogyakarta.

Arifin, E. Zaenal. 2015. Bahasa Indonesia sebagai Mata Kuliah Pengembangan Kepribadian. Tangerang: PT Pustaka Mandiri.

Arikunto, Suharsimi. 2011. Dasar-Dasar Evaluasi Pendidikan (Edisi Revisi). Jakarta: Bumi Aksara.

Azwar, Saifuddin. 2016. Reliabilitas dan Validitas Edisi 4. Yogyakarta: Pustaka Pelajar.

Brookhart, Susan M. 2010. How To Assess Higher Order Thinking Skills In Your Classroom. Massachusetts: ASCD.

Creswell, J.W. 2005. Educational Research: Planning, Conducting and Evaluating Quantitative and Qualitative Research, $2^{\text {nd }}$ Edition. Pearson Merrill Prentice Hall.

. . 1998. Qualitative Inquiry and Research Design: Choosing among Five Traditions. London: SAGE Publications.

Darini, N.M. dkk. 2013. Analisis Kualitas Tes Sumatif Bahasa Indonesia Kelas VIII SMPN 8 Denpasar Semester Genap Tahun 2012. e-Journal Program Pascasarjana Universitas Pendidikan Ganesha, Vol.2. 
Budapest International Research and Critics in Linguistics and Education (BirLE) Journal

Volume 2, No 2, May 2019, Page: 250-267

e-ISSN: 2655-1470 (Online), p-ISSN: 2655-2647 (Print)

www.bircu-journal.com/index.php/birle

emails: birle.journal@gmail.com

birle.journal.qa@gmail.com

Djiwandono, M. Soenardi. 2008. Tes Bahasa (Pegangan bagi Pengajar Bahasa). Jakarta: PT Indeks.

Febriani, Anita. dkk. 2013. Penggunaan Kaidah Bahasa Indonesia dalam Penulisan Soal Ulangan Semester Ganjil Kelas V SD Negeri 2 Rawa Laut Tahun Ajaran 2012/2013.Jurnal Kata (Bahasa, Sastra, dan Pembelajarannya). FKIP Universitas Lampung.

Gantamitreka, Sokha. 2016. Kesalahan Berbahasa: Penggunaan EYD Sesuai Permendikbud 2015. Solo: Genta Smart Publisher.

Handani, Herika Ambar Tri. 2015. Validitas dan Reliabilitas Soal Tengah Semester Genap Kaitannya dengan Ketercapaian Tujuan Pembelajaran Bahasa Indonesia Kelas VIII A SMP Negeri 2 Banyudono Tahun Pelajaran 2013/2014. PBSI FKIP UMS. Universitas Muhammadiyah Surakarta.

Hartono. 2015. Analisis Item Instrumen. Riau: Zanafa Publisihing.

Haryati, Mimin. 2010. Model \& Teknik Penilaian pada Tingkat Satuan Pendidikan. Jakarta: Gaung Persada Press.

Jandaghi, Gholamreza. 2010. Assessment of Validity, Reliability and Difficulty Indices for Teacher-Built Physics Exam Questions in First YearHigh School. Journal of Educational Research and Review. Iran. Vol. 5 (11).

. 2008. Validity, Reliability and Difficulty Indices for Instructor-Built Exam Questions. Journal of Applied Quantitative Methods (JAQM). Iran. Vol. 3, No.2.

Kara, Filiz. 2015. Development of Achievement Test: Validity and Reliability Study for Achievement Test on Matter Changing. Journal of Education and Practice. Turkey. Vol. 6. No. 24.

Karomani. 2009. Logika. Yogyakarta: Graha Ilmu.

Moser, C. A. \& Kalton, G. 1989. Survey Methods In Social Investigation. Aldershot: Gower.

Mushoffa dan Burhan Nurgiyantoro. 2015. Telaah Soal Uji Coba I Bahasa Indonesia di SMP Kabupaten Wonosobo Tahun 2013.Jurnal Lingtera, Vol. 2. No. 2.

Nugroho, R. Arifin. 2018. HOTS (Higher Order Thinking Skills). Jakarta:PT. Gramedia Widiasarana Indonesia.

Nurgiyantoro, Burhan. 2013. Penilaian Pembelajaran Bahasa Berbasis Kompetensi. Yogyakarta: BPFE.

Nurgiyantoro, Burhan, Gunawan dan Marzuki. 2009. Statistik Terapan untuk Penelitian IlmuIlmu Sosial. Yogyakarta: Gadjah Mada University Press.

Oller, J.W. 1979. Language in Education, Testing the Test. Rowley: Newbury House Publisher, Ins.

1979. Language Test at School. London: Longman Group Ltd.

Onosko, J.J., \& Newmann, F. M. 1994. Creating Powerful Thinking inTeachers and Students Diverse Perspectives. Fort Worth: Brace College Publishers.

Osadebe, P.U. 2015. Construction of Valid and Reliable Test for Assessment of Students. Journal of Education and Practice.Nigeria. Vol. 6. No. 1.

Permendikbud. 2016. Peraturan Menteri Pendidikan dan Kebudayaan Republik Indonesia Nomor 23 tahun 2016 tentang Standar Penilaian Pendidikan. Jakarta: Kemedikbud.

Prihati, Septimar. 2015. Analisis Deskriptif Kemampuan Guru dalam Menyusun Soal Ujian Sekolah (US) SMA Tahun 2014-2015.Jurnal Konferensi Ilmiah Tahunan Himpunan Evaluasi Indonesia (HEPI), ISBN 978-602-71325-7-3, pp 193-204.

Purwanto. 2017. Evaluasi Hasil Belajar. Yogyakarta: Pustaka Pelajar.

Puspendik. 2007. Panduan Penulisan Soal Pilihan Ganda. Jakarta: Balitbang Depdiknas. 
_ 2016. Panduan Penulisan Soal. Jakarta: Balitbang Depdiknas.

Putrayasa, Ida Bagus. 2010. Kalimat Efektif(Diksi, Struktur, dan Logika). Bandung: PT Refika Aditama.

Rahayu, Eny Putri dan Sukanti. 2013. Analisis Butir Soal Ulangan Kenaikan Kelas Ekonomi Akuntansi. Jurnal Pendidikan Akuntansi Indonesia, Vol. XI. No. 1.

Razali. 2012. 'Analisis Penggunaan Bahasa Indonesia dalam Soal Ebtanas SLTA'.Tesis: Program Pascasarjana UPI.

Rika Dwi Wibowo. 2009. Analisis Butir Soal Ulangan Umum Ekonomi Kelas XI IPS Semester Ganjil SMAN 1 Pakem, Sleman Yogyakarta Tahun Ajaran 2008/2009. Jakarta: UNY.

Safari. 1995. Kaidah Bahasa Indonesia dalam Penulisan Soal. Jakarta: PT. Kertanegara.

Sanjaya, Wina. 2013. Kurikulum dan Pembelajarannya. Jakarta: Kencana Prenada Media Group.

Sarea, Muh Syahrul. 2015. Analisis Kualitas Soal Ujian Akhir Semester Mata Pelajaran Kimia SMA di Kabupaten Gowa.Jurnal Konferensi Ilmiah Tahunan Himpunan Evaluasi Indonesia (HEPI) "Peranan Asesmen dan Ujian dalam Peningkatan Mutu Pendidikan Nasional”, ISBN 978-602-71325-7-3, pp 19-26.

Sevilla, Consuelo G. dkk. 2006. Pengantar Metode Penelitian. Diterjemahkan oleh: Alimuddin Tuwu. Jakarta: Universitas Indonesia.

Surapranata, Sumarna. 2009. Analisis, Validitas, Reliabilitas, dan Interpretasi Hasil Tes Implementasi Kurikulum 2004. Bandung: PT Remaja Rosdakarya.

Susetyo, Budi. 2015. Prosedur Penyusunan \& Analisis Tes untuk Penilaian Hasil Belajar Bidang Kognitif. Bandung: PT Refika Aditama.

Taherdoost, Hamed. 2016. Validity and Reliability of the Research Instrument; How To Test the Validation of a Questionnaire/Survey In a Research.. International Journal of Academic Research in Management (IJARM).Switzerland. Vol. 5, No. 3, 2016, Page: 2836, ISSN: 2296-1747.

Widjono. 2012. Bahasa Indonesia: Mata Kuliah Pengembangan Kepribadian di Perguruan Tinggi. Jakarta: PT Gramedia Widiasarana Indonesia.

Widoyoko, Eko Putro. 2014. Penilaian Hasil Pembelajaran di Sekolah. Yogyakarta: Pustaka Pelajar.

_ 2013. Teknik Penyusunan Instrumen Penelitian. Yogyakarta: Pustaka Pelajar.

Widyaningrum, Frisca Ayu Desi. 2012. Content Validity and Authenticity of the 2012 English Test in the Senior HighSchool National Examination. LLT Journal. Vol. 16, No. 1, ISSN 1410-7201.

Winata, Ni Putu Sintya, Ida Bagus Putrayasa, I Nyoman Seloka Sudiara. 2014. Analisis Butir Soal Pilihan Ganda Mata Pelajaran Bahasa Indonesia SMK Negeri 3 Singaraja. Jurnal Pendidikan Bahasa dan Sastra Indonesia. Vol. 2. No. 1. 